\title{
Lessons on the relationship between livestock husbandry and biodiversity from the Kenya Long-term Exclosure Experiment (KLEE)
}

\author{
Corinna Riginos ${ }^{1,2}$, Lauren M Porensky ${ }^{2,3}$, Kari E Veblen ${ }^{2,4}$, Wilfred O Odadi ${ }^{1,2}$, Ryan L Sensenig ${ }^{2,5}$, \\ Duncan Kimuyu ${ }^{2,6}$, Felicia Keesing ${ }^{7}$, Marit L Wilkerson ${ }^{2,3}$ and Truman P Young ${ }^{2,3^{*}}$
}

* Correspondence: tpyoung@ ucdavis.edu

${ }^{2}$ Mpala Research Centre, P.O. Box 555, Nanyuki, Kenya

${ }^{3}$ Department of Plant Sciences, University of California, Davis, CA 95616, USA

Full list of author information is available at the end of the article

\begin{abstract}
Although livestock and wildlife share most of their ranges worldwide, little controlled experimental research has been done on their interactions. Since 1995 we have been manipulating the presence of cattle and large wild ungulates in a Kenyan savanna rangeland in order to better understand the nature of competition and coexistence between these two guilds of herbivores and how they affect biodiversity. In a replicated experiment in which different combinations of cattle and wild herbivores are allowed access to large-scale plots, we have been monitoring the impacts of these herbivores on vegetation, on the wild herbivores, and cattle themselves, and on a variety of other taxa. We have also been conducting experimental research to examine other ways in which livestock management in eastern Africa might affect biodiversity. These include studies on the impacts of fire, livestock corrals, and changes in tree density. This research has revealed the following patterns. (1) Cattle suppress many species of wild herbivores, presumably through competition for their shared resources. The nature of this competition, however, is contingent on rainfall and the presence of other herbivores. (2) Wild herbivores both compete with and facilitate cattle, depending on rainfall. (3) The pastoral practice of housing livestock nightly in protective corral enclosures ("bomas") over time produces long-lived nutrient hotspots preferred by both livestock and wild herbivores. (4) Fire, frequently used by pastoralists in the past, is valuable for improving grass quality, with benefits for many species of wild herbivores. (5) Pastoral practices that reduce woody cover, including burning and boma construction, create local habitat patches that are preferred by wild herbivores, apparently for their greater anti-predator visibility. (6) Despite competition between livestock and wild herbivores, coexistence between these two guilds can be managed, and there are several positive (facilitative) pathways between livestock husbandry and wild herbivores and other biodiversity.
\end{abstract}

Keywords: Competition, Encroachment, Landscape, Fire, Boma, Kraal, Compatibility

\section{Introduction}

The relationship between pastoralism and biodiversity has been the subject of much discussion, but relatively little experimental research. The traditional view is that the relationship is largely antagonistic. An alternative view is that pastoralism in Africa (and much of Central Asia) has been compatible with biodiversity for hundreds and even thousands of years and does not necessarily cause degradation (e.g., Homewood 
and Rodgers 1984). Currently, there is a growing consensus that pastoralist livestock husbandry practices (at least at moderate intensity) are less damaging to rangeland resources than previously thought (Boyd et al. 1999; Reid 2012). Indeed, recent research has suggested that moderate livestock densities may even be beneficial to biodiversity (Gregory and Sensenig 2010; Soderstrom and Reid 2010; Augustine et al. 2011; Woodroffe 2011; Reid 2012). Here, we briefly review these alternate views and then summarize the scientific evidence emerging from projects associated with the Kenya Long-term Exclosure Experiment (KLEE) that shed light on the relationship between livestock (and various practices associated with livestock husbandry) and biodiversity (particularly wild ungulates) in the savannas of eastern and southern Africa.

\section{Pastoralism and biodiversity}

It is widely believed that rising numbers of pastoralist-owned livestock have led to rangeland degradation (Herlocker 1996) and a loss of biodiversity (Prins 1992, 2000; Reid 2012). In particular, livestock are blamed for the documented declines in large mammalian wildlife species in Africa (Ottichilo et al. 2000; Georgiadis et al. 2007; Ogutu et al. 2009, 2011). Pastoral practices in Africa have also been associated with increased bush encroachment (Archer 2010) and invasive weeds (Witt and Nongogo 2011).

At the same time, there are several pathways by which native biodiversity negatively impacts the enterprise of livestock production (Dunham et al. 2003; Sitters et al. 2009). First, wildlife competes with livestock, consuming forage resources, altering livestock behaviors, and reducing livestock productivity (Odadi et al. 2011). Second, pastoralists lose livestock-ranging from sheep and goats to cattle and camels-to wild predators (Atickem et al. 2010; Zimmerman et al. 2010). Lastly, there are complex disease interactions among wildlife, livestock, and other domestic animals, with negative repercussions for all of these guilds (see Grootenhuis 1999; Osofsky et al. 2005; Kock et al. 2010).

Despite these conflicts between biodiversity and livestock, the fact that African savannas have until recently maintained both thriving pastoral economies and densities of large mammalian wildlife (including both herbivores and predators) greater than anywhere else on earth is testament to their potential compatibility (du Toit et al. 2010; Reid 2012). Moreover, much of the argument that livestock and wildlife are incompatible is based on inference and anecdote, rather than experimental evidence. Our research, based on several replicated, large-scale experiments, suggests various positive and negative relationships between livestock husbandry and biodiversity. Specifically, our experimental work explores four broad topics:

(1) Livestock and wild ungulate herbivores share a common resource base, but there have been no experiments detailing how this plays out for both herbivore guilds in terms of direct and indirect competition and possible facilitation (positive interactions).

(2) Livestock in large parts of eastern and southern Africa are often housed in temporary corrals (bomas) each night that, once abandoned, develop into long-term ecosystem "hot spots", with a variety of possible consequences for wild herbivores and other taxa. 
(3) Extensive burning of rangelands has until recently been commonly practiced by pastoralists (and commercial ranchers). Burned areas have the potential to provide important grazing habitats for many species of wild herbivores.

(4) Boma construction, burning, and other human activities such as fuelwood harvesting, reduce tree densities. Conversely, woody plant cover is increasing in many rangelands, a change that has been attributed both to heavy grazing and increasing atmospheric $\mathrm{CO}_{2}$. Variation in tree density may have profound implications for wild herbivores in these mixed-use landscapes.

Through reviewing our findings about these interactions among wild herbivores, livestock, and various practices commonly employed by pastoralists, our purpose is to illustrate the diversity of positive and negative interactions and suggest how pastoralism and biodiversity conservation may be compatible.

\section{Caveat}

Pastoralism as a livelihood in Africa can take a number of forms, ranging from a truly nomadic to a mostly sedentary lifestyle, and from low to high stocking densities. Pastoralists keep a variety of different livestock, including cattle, sheep, goats, camels, and donkeys. Thus, "pastoral management" can mean many different things. Moreover, most pastoralist systems are dynamic, responding to changing conditions brought about by bio-physical factors such as rainfall, as well as socio-economic factors such as access to markets, security issues, or changes in land tenure or lifestyle often imposed by outsiders. Our intent here is not to discuss "pastoralism" as a fixed management system. Further, we acknowledge that no controlled experiments can mimic land management as practiced by diverse people across large areas of land. Rather, we illustrate some of the possible impacts that may be brought about by particular activities in which many pastoralists in eastern Africa (and to some extent southern Africa) engage. These activities include livestock grazing (here, we focus on cattle grazing), constructing corrals where livestock spend the night, using fire to improve or manage forage for livestock, and cutting wood for domestic use or commercial charcoal production.

\section{Laikipia and KLEE}

We have been studying the interactions among livestock, wild ungulate herbivores, and the land they share at the Mpala Research Centre and Ranch in Laikipia, Kenya, since 1992 (Figure 1). The landscape in this region is a semi-arid savanna dominated by perennial grasses and Acacia trees. This region is rich in wildlife and also supports numerous private cattle ranches as well as Maasai and Samburu pastoralists living on "group ranches". Common wild ungulate species in this region include elephant, plains zebra, Grant's gazelle, impala, eland, oryx, hartebeest, and buffalo. Common large predators include lion, leopard, cheetah, and hyena. The region is also home to critical populations of endangered African wild dog, Grevy's zebra, and black rhinoceros. Unlike other parts of Kenya, this region has seen an increase in the populations of many wildlife species in recent decades (Georgiadis 2011; M. Kinnaird et al., unpublished data). Although these increases have largely occurred on privately owned ranches, innovative conservation and 


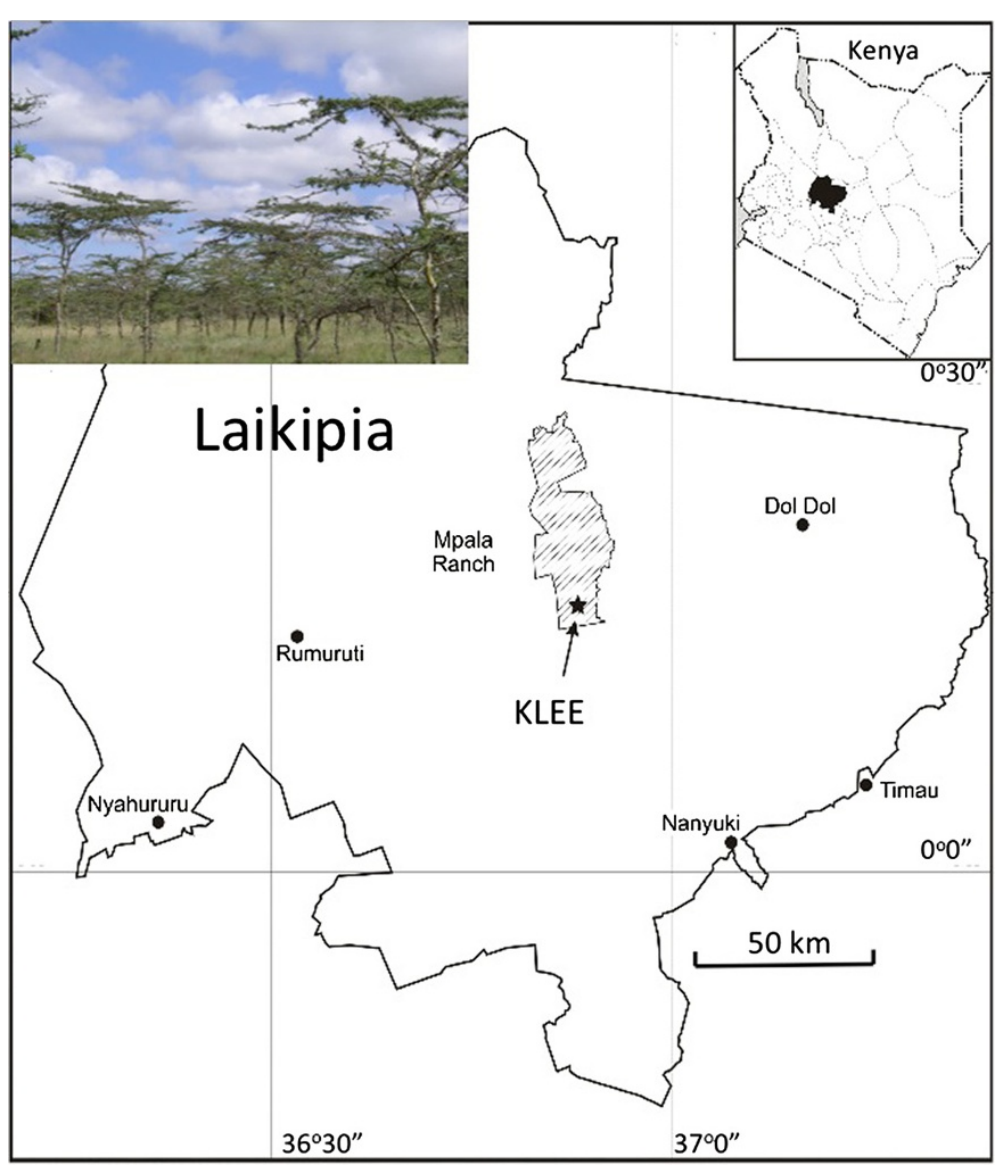

Figure 1 Laikipia County (District) in Kenya, with the location of the Mpala Ranch and Conservancy, and the KLEE exclosures. Inset: Acacia drepanolobium-wooded grassland.

tourism partnerships between these ranches and pastoralist communities raise hope that these trends will continue into the future (Sundaresan and Riginos 2010).

The focus of this study in this system is the Kenya Long-term Exclosure Experiment (KLEE). This large-scale, experiment consists of eighteen 4-ha plots that were established in 1995. The plots allow six combinations of (1) cattle, (2) wild herbivores $>15 \mathrm{~kg}$, and (3) mega-herbivores (elephants and giraffes), replicated across three blocks. These three herbivore classes are labeled C, W, and M, respectively, in Figure 2 (with "O" representing no large herbivores). Wild herbivores are allowed to come and go freely (except where they are experimentally excluded). Dung surveys suggest that wild ungulates use areas inside and outside of the plots at similar rates. Cattle use of the plots is regulated through regular "cattle runs", where herds of approximately 120 cattle are individually herded into designated plots approximately 6 times per year, which approximates the (moderate) stocking densities and return intervals of cattle on the ranch $\left(0.15-0.20\right.$ cattle $\left./ \mathrm{km}^{2}\right)$. For details of the experimental design, see Young et al. (1998).

KLEE represents the first controlled, factorial, experimental study in any ecosystem of the interactive effects of different domestic and native herbivores on each other and on their shared ecosystem. This study has also been extended to include several other 


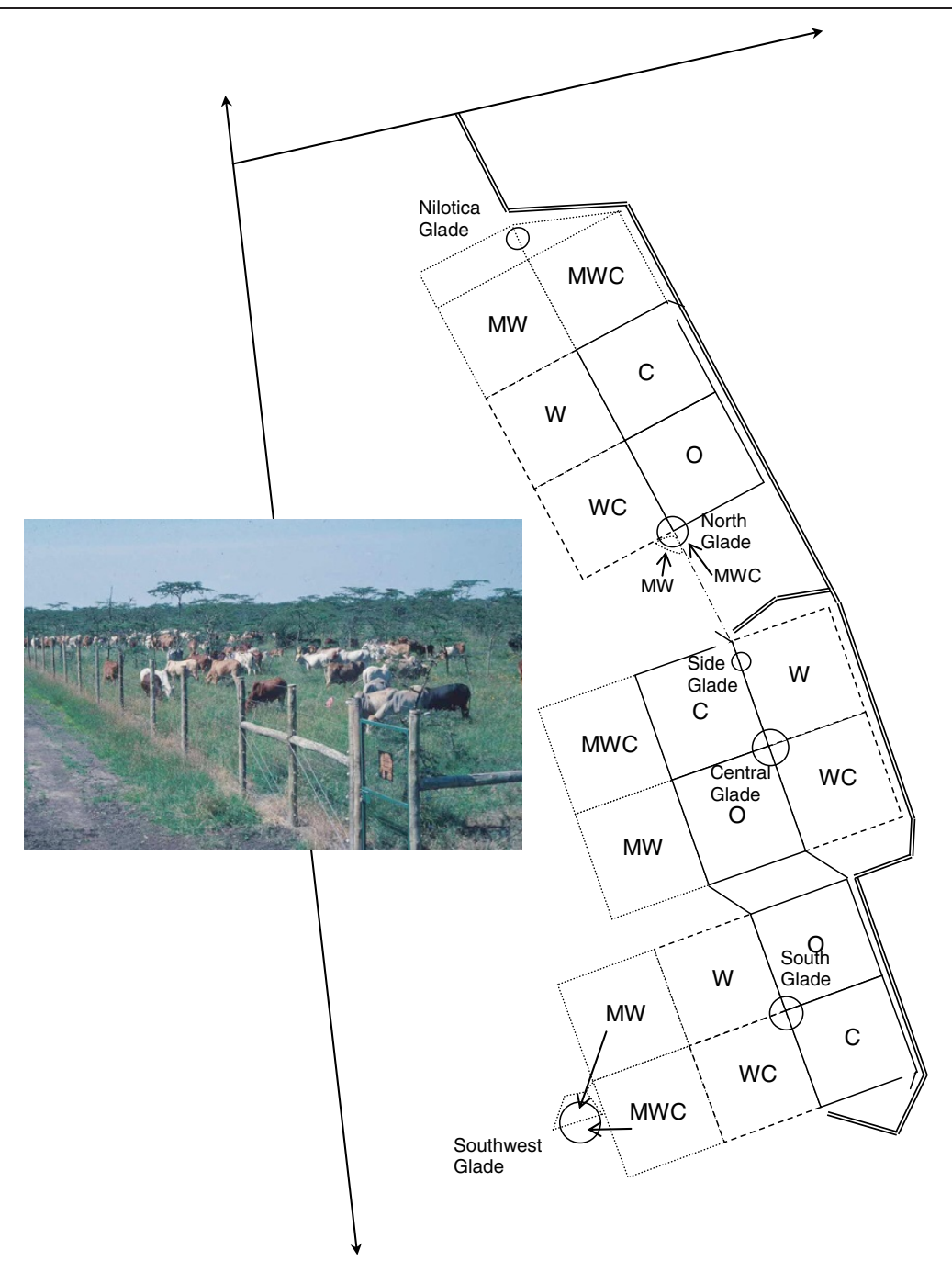

Figure 2 Schematic of the KLEE. Letters inside each plot indicate the herbivores allowed: C, cattle; W, wildlife >15 kg; M, mega-herbivores (elephant and giraffes); O, no large herbivores allowed.

experiments in the same landscape that manipulate fire, bomas, and tree density. Descriptions of these experiments are given below.

\section{Key findings}

\section{Impacts of cattle on wildlife}

In over 15 years of work in KLEE, we have found that cattle suppress a broad spectrum of wild herbivore species, presumably through competition for shared forage resources. Wild herbivore use of these plots has been measured by counting dung piles along permanent transects that have been sampled twice-yearly since 2006. Dung density of all species was, across all sample periods $2006-2011$, 44\% greater in plots from which cattle have been excluded. Cattle reduced herbivore use for each of the four most common, medium-sized wild herbivore species: plains zebra, Grant's gazelle, eland, and oryx (Figure 3). Although cattle are primarily grazing herbivores, their diet at our study site can be as much as $15 \%$ forbs (non-grass herbs) (Odadi et al. 2007), and this is 


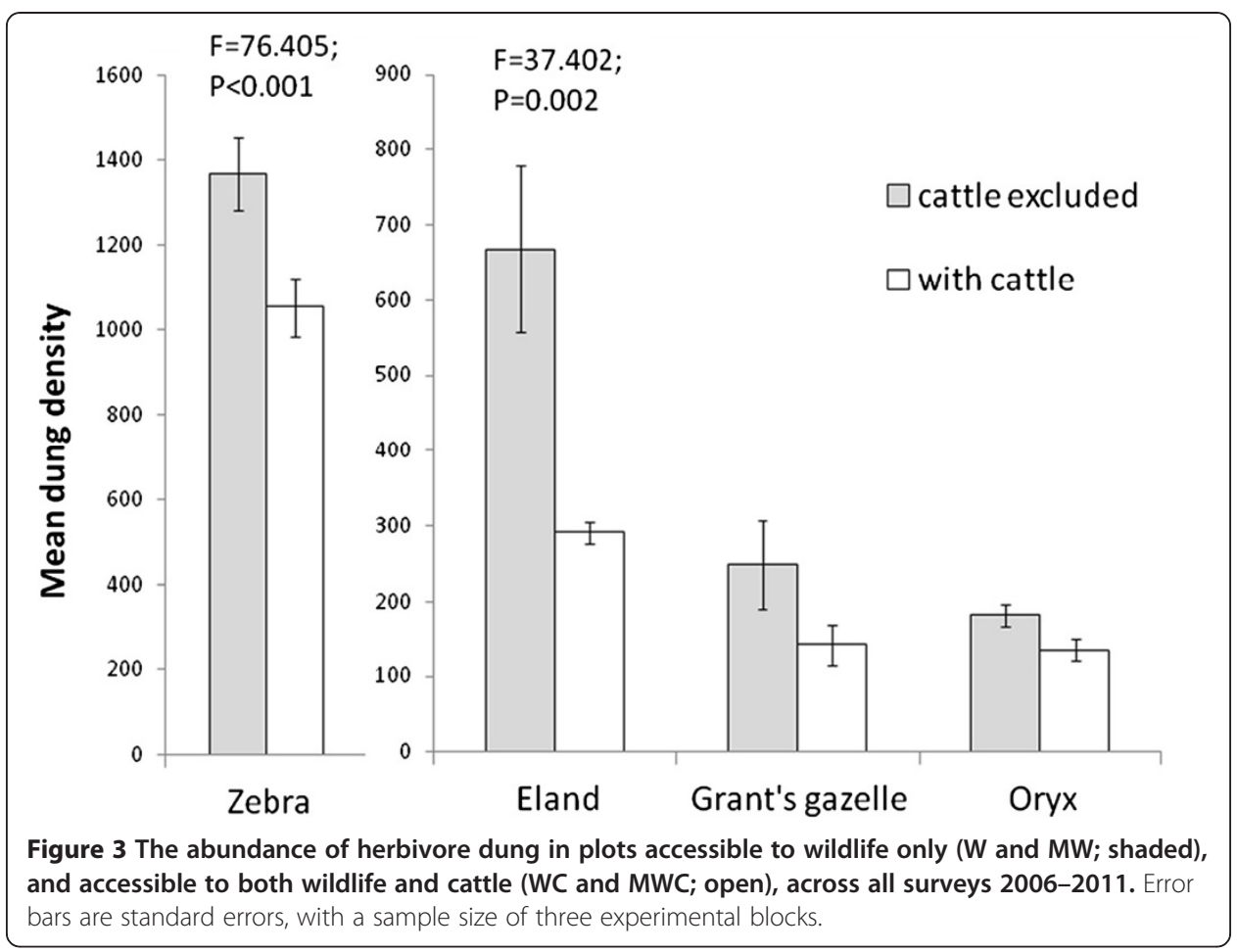

reflected in their ability to competitively suppress not only grazing wildlife, but also mixed feeders. None of these reductions is likely due to direct interactions with cattle or herders; cattle herds are present in the designated plots for only 12-16 h per year. Instead, cattle are consuming forage that would otherwise support wild herbivore species.

Mega-herbivores (elephants, mainly) can potentially mitigate this competition between cattle and other wild herbivores. In the absence of elephants, cattle reduced overall wild herbivore density in $2006-2011$ by $39 \%$, whereas when elephants were present cattle reduced wild herbivore density by only $26 \%$. In a previous study in KLEE, cattle reduced zebra use of the plots by $44 \%$ in the absence of elephants, but cattle reduced zebra use by only $18 \%$ in the presence of elephants (Young et al. 2005). In other words, elephants ameliorate the competition between cattle and wild herbivores, especially zebras. This surprising indirect facilitation is likely because (a) elephants eat forage that other wild herbivores might otherwise eat, reducing habitat use by zebras in the absence of cattle, and (b) cattle appear to eat less (reduce the forage less) when they share their forage base with elephants, increasing habitat use by zebras. Taken together, these results illustrate that grazing by domestic livestock does competitively suppress wild ungulate herbivores, but perhaps to a lesser degree than previously thought.

\section{Special story: rodents}

Another set of actors ameliorating competition between cattle and wild herbivores lies at the opposite end of the size spectrum: rodents. These "cryptic consumers" (Keesing 2000) also increased in plots from which we have excluded large herbivores. In plots where all large herbivores (both cattle and wild herbivores) are excluded, rodents have doubled in numbers, eating an estimated half of the forage 
that is made available (Keesing 1998). When only cattle or only wild herbivores are excluded, the rodent response is intermediate (Goheen et al. 2010). This means that when managers estimate how much additional forage will be available if they eliminate grazing wildlife, they are likely to over-estimate the benefits by an appreciable margin (perhaps 25\%). Conversely, estimates of how much more wild herbivore biomass an ecosystem would support if all livestock were removed would be similarly over-estimated if rodents are not considered.

\section{Impacts of wild ungulate herbivores on cattle}

Another set of findings from our work in KLEE indicates that wild herbivores competitively suppress cattle, but again, to a lesser degree than scientists and managers have often assumed. In a series of experiments, we assessed the effects of wild herbivores on cattle foraging behavior, nutrition, and performance (weight gain) during dry and wet seasons (Odadi et al. 2007, 2009, 2011). We also measured vegetation cover (the forage available to the cattle) during these trials. Our results (Table 1) show that the effects of wild herbivores on cattle differ markedly between wet and dry seasons.

During the dry season, wild herbivores had a number of negative effects on cattle. Cattle bite rate decreased and step rate increased, leading to fewer bites per step. This was associated with reduced forage, reduced overall food intake, and reduced relative intake of forbs and the perennial grass Pennisetum stramineum. As a consequence of these changes in foraging behavior, weight gain by cattle also

Table 1 Effects of the presence (versus exclusion) of wildlife on the foraging behavior, forage selection, food intake, diet quality and weight gain by cattle during wet and dry seasons

\begin{tabular}{|c|c|c|}
\hline & Dry season & Wet season \\
\hline \multicolumn{3}{|l|}{ Foraging behavior } \\
\hline Bite rate & Decrease & No effect \\
\hline Step rate & Increase & No effect \\
\hline Bites per step & Decrease & No effect \\
\hline Relative bites on forbs & Decrease & No effect \\
\hline Relative bites on $P$. stramineum & Decrease & No effect \\
\hline Food intake & Decrease & No data \\
\hline \multicolumn{3}{|l|}{ Diet quality } \\
\hline Dietary crude protein content (CP) & No effect & Increase \\
\hline Dietary digestible organic matter content (DOM) & No effect & No effect \\
\hline Dietary DOM/CP ratio & No effect & Decrease \\
\hline \multicolumn{3}{|l|}{ Performance } \\
\hline Weight gain & Decrease & Increase \\
\hline \multicolumn{3}{|l|}{ Herbaceous vegetation } \\
\hline Overall grass cover & Decrease & No effect \\
\hline Cover of forbs & Decrease & No effect \\
\hline Cover of $P$. stramineum & Decrease & Decrease \\
\hline Cover of dead stems & No effect & Decrease \\
\hline
\end{tabular}

"No effect" means no statistically significant effect. 

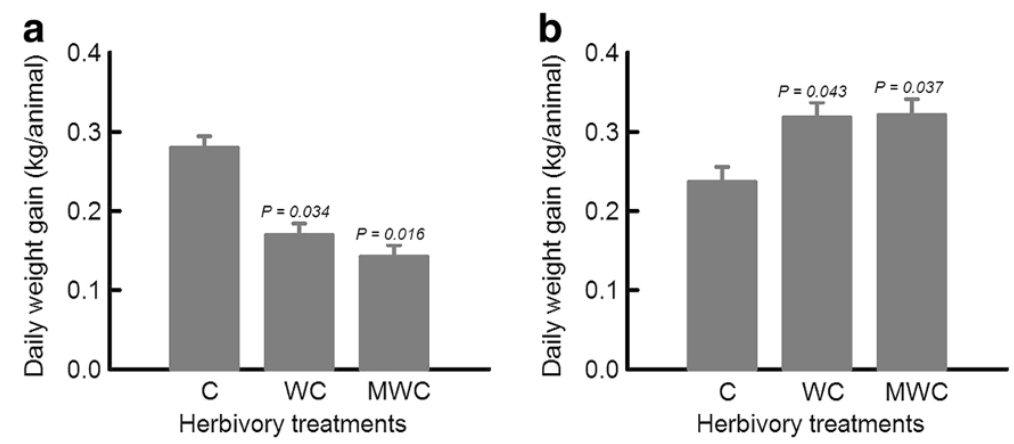

Figure 4 Cattle weight gain in the presence and absence of wildlife, during (a) dry periods and (b) wet periods. Figure adapted with permission from Odadi et al. (2011).

decreased when cattle shared forage with wild herbivores during dry periods (Figure 4). Cattle that grazed in areas not shared with wild herbivores gained weight $37 \%$ faster.

Decreased bite rate and bites per step and increased step rate in the shared plots suggests that cattle sharing land with wild herbivores forage less efficiently during dry periods because they travel more between feeding stations and take fewer bites at each station (see also Ungar and Noy-Meir 1988; Spalinger and Hobbs 1992; Bradbury et al. 1996). These wildlife-driven effects on foraging patterns appear to cause cattle to expend more energy and thus gain less weight (Odadi et al. 2011). Decreased consumption of forbs (non-grasses) by cattle when they forage in the same areas as wild herbivores is related to reduced availability (cover) of this forage class. Forbs contain higher protein levels than grasses (Boutton et al. 1988; Kinyamario and Macharia 1992) and are thus an important forage resource for herbivores. Although cattle are primarily grazers, inclusion of forbs in their diet may enhance their nutritional status, especially during the dry season when nutrient content of grasses is low. Depressed cattle weight gain in the shared plots during the dry season was also associated with decreased food intake and reduced relative consumption of the high protein-content grass $P$. stramineum. These findings provide some of the first experimental evidence to support the long-held assumption that wild herbivores compete with cattle for food.

However, the story is not one of simple competition. During the wet (growing) season, the presence of wild herbivores enhanced cattle weight gain (Figure 4), indicating a facilitative interaction (Odadi et al. 2011). This positive interaction was driven by improved forage quality due to reduced cover of dead grass stems in areas where wild herbivores also grazed. This facilitation appears to be largely driven by zebras, which are known to consume dead grass parts and have been observed to enhance the quality of forage available to other wild herbivores (Gwynne and Bell 1968; Duncan et al. 1990).

These findings indicate that although grazing wild herbivores do compete with cattle in dry periods, they at least partially compensate for this by facilitating cattle in wet periods. These findings suggest that wild herbivores are not uniformly detrimental to livestock production, improving the prospect that wildlife conservation and economic development can both be achieved in savanna rangelands. 


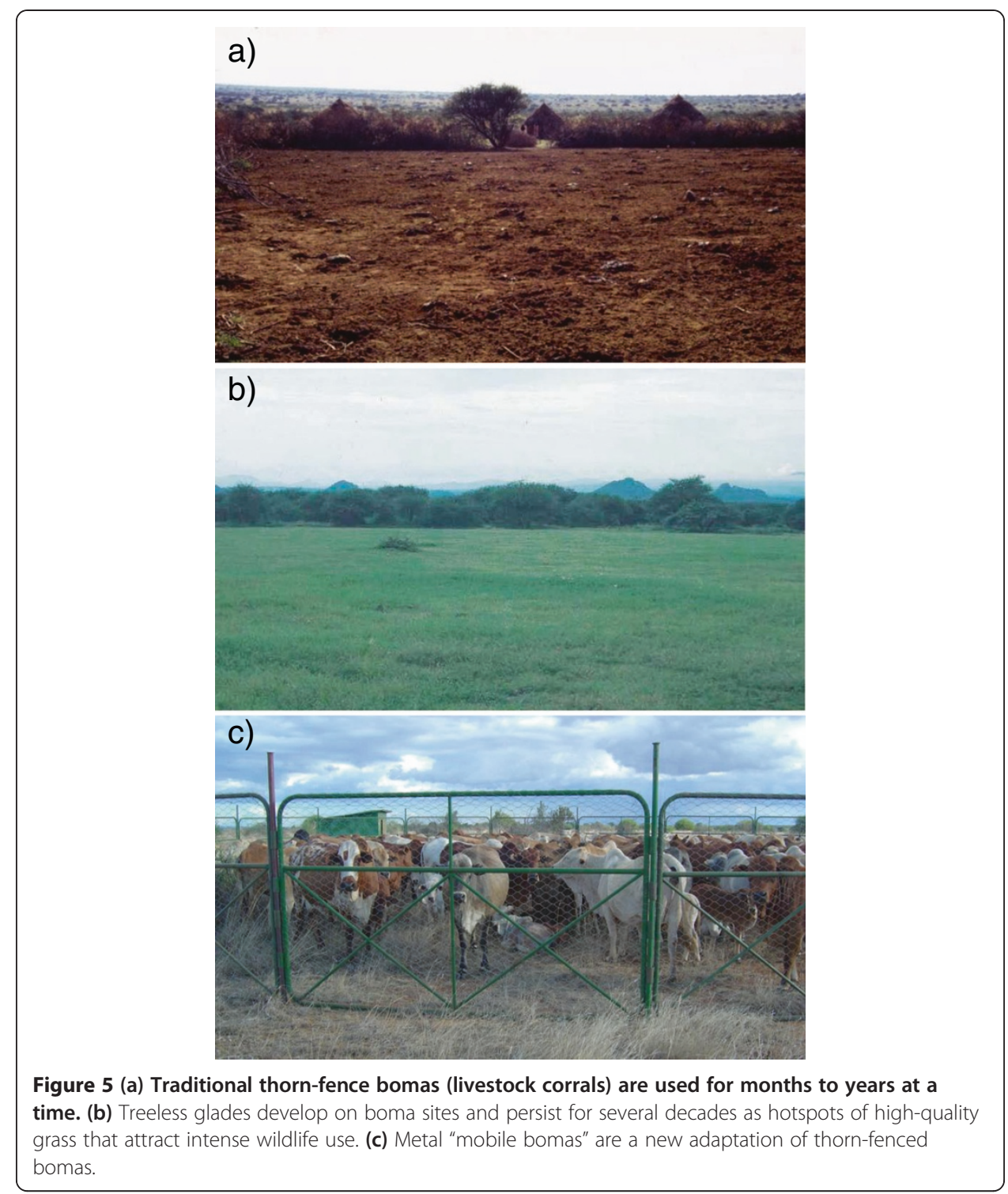

\section{Long-term effects of traditional livestock bomas}

Throughout the savannas of eastern Africa and parts of southern Africa, bomas (temporary thorn-fence livestock corrals; Figure 5a) have been used for centuries by pastoralists to corral livestock overnight for protection from both predators and stock raiders (Western and Dunne 1979). During the colonial era (a time of suppressed lion populations), traditional bomas on many of Laikipia's commercial ranches were replaced by (non-thorn) wooden fence corrals, presumably because the threat of livestock predation declined (P. Jessel, personal communication). In recent decades, predator populations (including lions) have begun to recover in some parts of Laikipia, and thorn bomas continue to be an important element of economic and cultural life on both communally and privately managed lands.

A given boma may be used for months or years at a time before a new boma is established elsewhere (Western and Dunne 1979). While they are actively being used, bomas can have a number of negative impacts on wild herbivores and other taxa. Scores of 
trees in the vicinity are harvested to build the boma fences. The intensive grazing around bomas can cause overgrazing, soil compaction and, over time, land degradation (Ringrose et al. 1996; Moleele et al. 2002; Muchiru et al. 2009). At the same time, wild herbivores avoid active boma sites, either because of the presence of people or competition for shared resources, or both (Sundaresan et al. 2007). Depending on the duration of boma use and the severity of the livestock's impacts on surrounding land, negative effects of a boma may persist for years, possibly even decades, after it is abandoned.

However, boma practices also have a number of more complex, often positive, impacts on wild herbivores and other biodiversity. Most notably, abandoned boma sites go on to become ecosystem hotspots for a variety of flora and fauna. After abandonment, a thick layer of livestock dung is left at the site, facilitating the establishment of nutrient-rich plant communities that persist for decades to centuries (Blackmore et al. 1990; Reid and Ellis 1995; Augustine 2003; Muchiru et al. 2009) and creating a treeless landscape feature called here a "glade" (Figure 5b). Glade sites have relatively low local plant diversity but their presence increases regional diversity by hosting plant species that are uncommon in or absent from the background savanna (Muchiru et al. 2009; Porensky 2011; Veblen 2012). Glades attract wild herbivores and cattle to graze on nutrient-rich grasses and rest in these open areas (Young et al. 1995; Augustine 2004; Muchiru et al. 2008; Veblen 2012). Our work has also shown that glades host increased densities of termites (Veblen 2008a), arboreal geckos and insects (Donihue paper is in revision at Ecology), and locally rare rodent species (Veblen 2008a). All of these results suggest that bomas and glades represent a rarely documented example of a positive, synergistic relationship between biodiversity conservation and livestock production. Because glade edge effects extend at least $100-\mathrm{m}$ into the surrounding savanna landscape (Young et al. 1995; Muchiru et al. 2009; Porensky 2011; Veblen 2012), these anthropogenic features influence extensive areas across the rangelands of eastern and southern Africa.

Our work in KLEE (which encompasses several glades) indicates that cattle and wild herbivores (particularly medium-sized herbivores) have contrasting impacts on herbaceous plant community succession in glades (Veblen and Young 2010). Over the long term, wild herbivores (mostly zebras), through their forage preferences, reinforce landscape heterogeneity by helping to maintain glades in a more palatable, early successional state. Cattle and mega-herbivore wildlife, on the other hand, appear to reduce this effect by preferentially foraging on early successional grass species, thereby favoring the later successional species (Veblen and Young 2010).

We have also found that cattle grazing alters the use of glades by wild herbivores. During the dry season, wild herbivore use of glades more than doubled when cattle were excluded (Porensky et al. in review). This response was driven by both grazing herbivores (zebra, hartebeest, and warthog) and mixed-feeding or browsing herbivores (eland, oryx, steinbuck, Grant's gazelle, bush duiker, and impala). Moreover, in the presence of cattle, wild herbivores showed little preference for glades (compared to the background savanna), but when cattle were excluded, wild herbivore use inside glades was at least 30\% higher than their use of areas far from glades. Other work (Veblen 2008b) suggests that glades may serve as important wild herbivore foraging areas during the dry season, when grass is scarce in non-glade areas (sensu Ilius and O'Connor). 
Together, these results from KLEE suggest that different types of herbivores (cattle, medium-sized wild herbivores, and mega-herbivores) interact in complex ways with glades. Through the creation of glades and by facilitating subsequent interactions between cattle and glades, traditional pastoralist management activities have had major impacts on savanna landscape heterogeneity and biodiversity.

\section{Bomas in the modern context}

As pastoral populations have grown and become more sedentary and the land available to them shrinks, livestock management practices and the ecological impacts of bomas are changing. Most pastoralists today cannot move as far or as frequently as their predecessors (Ensminger and Rutten 1991; Fratkin et al. 1999), and herders are forced to use smaller parcels of land more intensively. As a result of these processes, boma densities have increased dramatically in some parts of East Africa (Lamprey and Reid 2004), with detrimental impacts on widlife (Ogutu et al. 2010). Moreover, without sufficient land or mobility, livestock managers have difficulty allowing for the full recovery of intensively used areas around traditional boma sites.

In this context of increasing boma density and duration of use, bomas may lead to significant degradation of surrounding soils and plant communities. We have found that areas between two or more nearby glades ( $<150 \mathrm{~m}$ apart) are characterized by especially high tree densities and low wild herbivore use (Porensky 2011). This is likely due to a legacy of active boma use; the presence of cattle and humans during boma occupation may positively affect tree cover by reducing grass cover (and its competitive effects on trees) and browser presence, and by fertilizing areas between nearby bomas (L. M. Porensky unpublished data; Muchiru et al. 2009). Following boma abandonment, high tree densities between nearby glades probably deter wild herbivores by making predator detection more difficult (see below).

We have been exploring ways to reduce negative-and amplify positive-impacts of modern boma management. One potential tool that has been developed in Laikipia is the "mobile boma". Mobile bomas are made of moveable, metal fencing (Figure 5c) and can be used for short periods of time so that they have fewer degradative impacts but still create nutrient-rich grazing hotspots. Mobile bomas can be moved more frequently than traditional brush bomas because they do not require the labor or large number of trees that are needed to construct brush bomas. More frequent herd movement reduces overgrazing and trampling at any one site, potentially allowing areas to recover and be reoccupied sooner.

The advent of mobile bomas raises several key management questions and opportunities. Managers in Laikipia are now using mobile bomas to create wildlife hotspots for tourists and to restore grass in degraded, bare areas. Questions that remain to be answered about this new management tool include: Is there a minimum time that a boma must remain in place in order to create a wildlife hotspot? How often does a boma need to be moved in order to avoid over-use and degradation of a given site? How should managers arrange bomas across the landscape to minimize broad-scale degradation? We are currently investigating these questions experimentally with a view to providing practical recommendations for how managers can adapt this traditional 
management practice to improve forage quantity and quality for their livestock and provide nutrient hotspots for wildlife.

Fire

Fire has been structuring savanna and grassland systems for millennia. Gillson (2004) has recorded charcoal evidence of fire history over the last 1,400 years in Kenya. In Laikipia, burning was a common practice among both pastoralists and commercial ranchers until the early 1960s (Heady 1960). In focus group interviews, Maasai, Samburu, and Borana elders in Kenya and Ethiopia recalled burning every several years to control bush encroachment, control tick and tsetse fly populations, and remove rank or overgrown grass with a high ratio of dead stems-allowing newer, more palatable grass to grow in its place (C. Riginos, unpublished data). At present, most pastoralists and commercial ranchers in the region do not use fire as a management tool. On pastoralist-managed lands, this is largely because current grass cover is insufficient fuel to carry a fire and because people are hesitant to burn their dry season reserves. Most elders we have interviewed, however, agree that controlled burns offer a number of benefits to livestock and wildlife and claim they would resume burning if grass were not in such short supply.

To investigate the impacts of fire on wildlife in this region, we used multiple replicated prescribed burns on several commercial ranches in Laikipia to create habitat heterogeneity at multiple scales (Figure 6). We then measured the use of these sites by wild herbivores using repeated dung surveys. We also measured changes in grass quality and quantity in burned sites to estimate how forage dynamics influenced wild herbivore habitat use, with particular interest in determining whether a grazer's body size influenced its time spent in burned areas.

We found that prescribed burning creates heterogeneity in forage quality and quantity across the landscape that persists for several years after burning (Sensenig et al. 2010). The use of burn sites by wild herbivores does depend on a grazer's body size, with small-bodied animals using burn sites significantly more than large-bodied grazers (Sensenig et al. 2010). Foregut fermenters (ruminant herbivores) prefer burns more than hindgut fermenters (non-ruminants, e.g., zebras, elephants, and hares) of similar body size (Sensenig et al. 2010). This suggests that burns are especially important for maintaining populations of small-bodied and ruminant wild herbivores.

These herbivore responses to burning are also of management importance in many parts of eastern Africa where significant wild herbivore declines have been observed (Ottichilo et al. 2000). There is growing evidence that in some cases wild herbivore declines may be due to reduced grass structural heterogeneity-due to fire suppression in an otherwise fire-prone system-which may have negative repercussions for certain grazing herbivores. For example, over the last 20 years, Thomson's gazelle, Grant's gazelle, and wildebeest have declined in the Ngorongoro Crater in Tanzania, while the bulk forage feeder, the African buffalo, has increased (Estes et al. 2006). Fire exclusion since 1960s was cited as one of the multiple potential causes, which led to an increase in tall, poor quality grass at the expense of shorter, high-quality forage. Similar scenarios have been suggested for Nairobi National Park, Kenya (Gichohi 1992). 

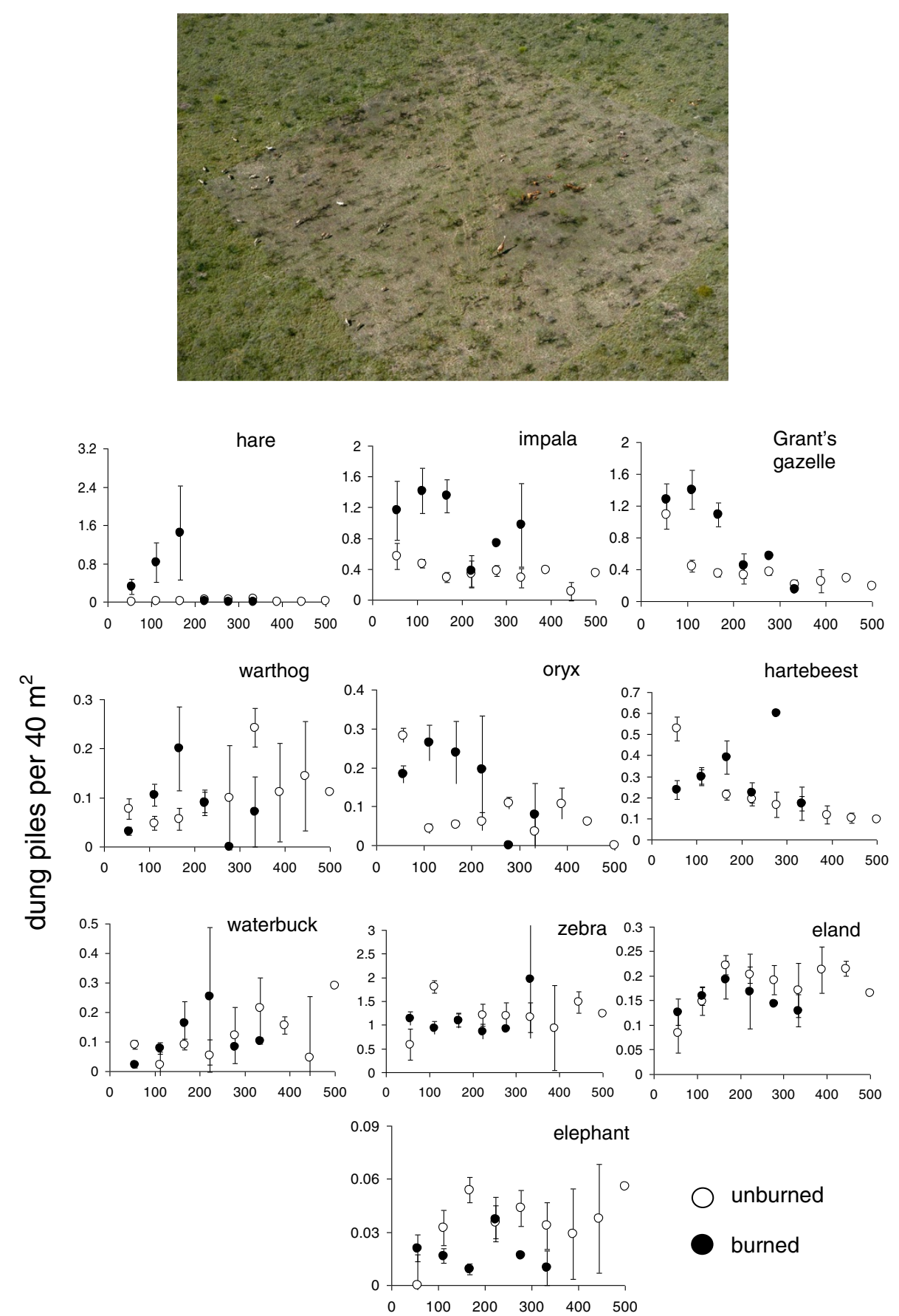

biomass of dead leaf \& stem $\left(\mathrm{g} / \mathrm{m}^{2}\right)$

Figure 6 Hartebeest, zebras, and giraffe attracted to a 1-ha burn in Laikipia, Kenya.

In a separate study in our ecosystem, we also demonstrated the effectiveness of fire in reducing woody vegetation (Okello et al. 2008). Eight years after a controlled burn, tree density was reduced by $64 \%$ inside the burn site relative to adjacent unburned 
areas. This reduction in tree density likely further enhances the grass productivity and quality of the habitat for a variety of wild herbivore species (see below).

Although many pastoralists do not currently use prescribed burns, our work illustrates that fire may still be an important and useful management tool; particularly in regions such as Laikipia where many pastoralist communities seek to attract wildlife and tourism to their land. For example, a shifting mosaic of relatively small burns might provide many of the benefits of burning (including providing more nutritious forage for livestock and controlling bush encroachment) without incurring large losses of forage at any one time. The global trend towards increased woody cover (Wigley et al. 2010) may also provide a renewed role for fire in controlling bush encroachment and maintaining a rangeland suitable for cattle and other grazing livestock. However, it is important to note that not all areas are amenable to burns. All of the burn plots in our study were located on black cotton vertisol soils receiving 500-700 mm mean annual rainfall. Fire-induced heterogeneity of grass swards is likely more important in these kinds of habitats where significant seasonal accumulation of grass biomass and declines in forage quality occur. In areas that are dominated by bare ground and eroding rapidly, a burn might remove litter and other important ground cover, accelerating erosion and degradation. In such areas, a period of rest from grazing (allowing grass to recover) followed by a controlled burn can be very effective at controlling woody vegetation and stimulating new grass production.

\section{Tree and shrub density}

People and their livestock affect the cover and density of woody plants (both trees and shrubs) in a variety of ways. Pastoralists cut woody stems for a number of purposes: as fuel for domestic fires or, more recently, to make charcoal for sale in urban areas, as brush walls for bomas, for construction of houses, and for medicinal purposes. This harvesting of woody vegetation can reduce the density and cover of trees and shrubs, particularly in areas where people are partly or fully sedentary. Pastoralists' browsing livestock (e.g., goats, camels) can also have a negative impact on woody plants, ultimately reducing their numbers. Finally, as discussed above, fire can reduce woody cover and density (Okello et al. 2008).

Other activities have the opposite effect, causing woody plants to increase in number. Fire suppression and heavy grazing have both been associated with increased numbers of trees and shrubs (so-called "bush encroachment"), especially around intensely grazed areas like water holes (Moleele and Perkins 1998) and bomas (see above, and Moleele et al. 2002). Through experimental removals of grass around trees, both inside the KLEE experiment and outside, we have shown that grass can have a strong, negative (competitive) effect on trees of all sizes-halving their rate of growth (Riginos and Young 2007; Riginos 2009). At the same time, the absence of browsers (e.g., where cattle have replaced wild herbivores) also enables trees to grow and reproduce more rapidly (Riginos and Young 2007; Maclean et al. 2011; Porensky and Veblen 2012). These studies together provide new insights into how livestock grazing affects woody cover. It is also important to note that local anthropogenic activities are likely acting in concert with a global increase in carbon dioxide to favor woody plants over grasses (Wigley et al. 2010; Archer 2010). 
Changing numbers of trees and shrubs can have a variety of consequences for native flora and fauna. Trees and shrubs provide essential habitat structure in the savanna landscape-for example, they provide perches and nest sites for birds (Ogada et al. 2008), food and domicile for insects, spiders, and invertebrates (Pringle et al. 2007), and a sheltered, nutrient-enriched habitat for a variety of understory plants. In the KLEE system, we have demonstrated that lower densities of a common shrub, Cadaba farinosa, are associated with lower abundances in several common butterfly species in the genus Colotis, whose adults and larvae specialize on Capparaceae (M. L. Wilkerson and T. P. Young unpublished data). Thus, an increase in trees and shrubs may be beneficial for overall ecosystem species diversity-up to a point. A very high density of woody vegetation, conversely, is likely to hinder the persistence of species that rely on open, grassy areas.

Similarly, changes in woody vegetation can have a variety of consequences for large herbivores, both wild and domestic. Increased woody vegetation may favor browsing herbivores; however, in many cases it is the less palatable trees and shrubs that tend to increase most aggressively. Through a large-scale manipulation of tree density in our study system, we have demonstrated that grass production is suppressed in areas with more trees (Riginos et al. 2009), reducing the forage available to grazing wildlife and livestock. Dense thickets of woody vegetation can also be physically impenetrable for livestock and wildlife alike. In some areas, these thickets tend to harbor tsetse flies and the diseases they carry.

Finally, our work has shown that many species of wild herbivores avoid areas of dense woody vegetation (Figure 7; Riginos and Grace 2008), most likely because the vegetation impedes their ability to detect and flee from predators. On the other hand, areas with few or no trees may not be suitable habitat for browsing herbivores or mixed-feeders. Trees, particularly larger ones, can enhance the nutrient content of the soil and grasses growing beneath them; thus, even grazing herbivores may suffer in areas from which all trees have been removed (Treydte et al. 2010).

Cattle (which are typically accompanied by herders in eastern Africa) appear not to be as sensitive to tree density as are wild herbivores (Figure 7; Riginos and Grace 2008; W. O. Odadi and C. Riginos, unpublished data), suggesting that competition between these guilds of herbivores may be lessened by focusing livestock grazing on more

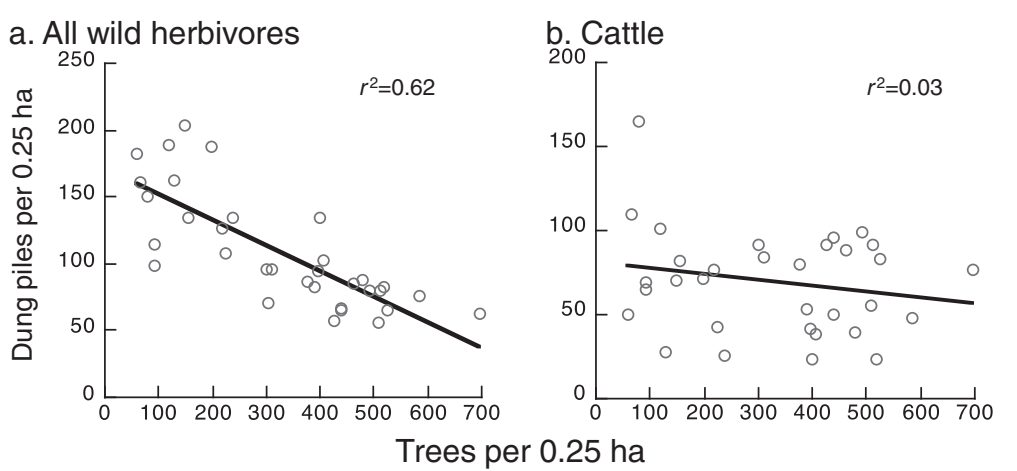

Figure 7 Dung densities indicate that wild herbivore species (predominantly plains zebra, Grant's gazelle, hartebeest, and oryx) generally prefer more open areas, while cattle use the landscape more indiscriminately. Figure printed with permission from Riginos and Grace (2008). 
densely wooded areas. During times of drought, however, many wild herbivore species that prefer open areas shift into more wooded areas if there is more grass in those areas (C Riginos, unpublished data). These results again highlight that season and habitat are important determinants of the strength of competition between wild herbivores and livestock.

The many ways in which pastoralists impact woody vegetation-and therefore wild herbivores and other biodiversity-suggest both an opportunity and a caution. Because people and their livestock can have numerous, opposing effects on woody cover, there is good reason to believe that the needs of both pastoralists and wild herbivores can be met in their shared habitat. A moderate density of a variety of tree and shrub species is most likely to benefit people, livestock, and a diverse community of wildlife. However, some heterogeneity in woody cover-including some densely wooded areas as well as open, grassy areas in addition to moderately woody areas-is most likely to benefit the greatest diversity of wildlife and other flora and fauna.

\section{Discussion}

Our results confirm that the relationship between livestock husbandry and wildlife is complex. On the one hand, we provide some of the first evidence from replicated, controlled experiments that cattle do reduce habitat use by native herbivores (even at moderate cattle stocking densities), and that wild herbivores can reduce livestock productivity. This competition extends to browsing and mixed-feeding herbivores, suggesting that estimates of competition based on dietary overlap may underestimate its strength; even partial overlap on minority components of the diet may be important (limiting). On the other hand, our research has begun to reveal a wide variety of more positive relationships between livestock and wild herbivores. This includes not only direct facilitation of wild herbivores by cattle (particularly during the wet season), but also several indirect benefits brought about by livestock management activities, particularly the use of bomas and fire as well as various management impacts on woody cover.

More generally, our findings suggest that pastoralists (as well as other land or livestock managers) can minimize negative interactions and maximize positive interactions through two means: first, by minimizing competition between wild herbivores and livestock during the dry season; and second, by maintaining or increasing habitat heterogeneity. Minimizing competition might be achieved through avoiding critical wildlife habitat during dry times. A more heterogeneous landscape may also afford more refugia for wildlife in times of drought. Realistically, however, it may be difficult to minimize competition and land degradation unless pastoralists destock during or in anticipation of dry periods and then later restock. Drought index insurance programs (Hazell and Hess 2010) and slaughter off-take programs (Zwaagstra et al. 2010) may provide incentives to destock where conventional, commercial market sales are not a feasible option.

Habitat heterogeneity can be maintained or increased through the mechanisms we have discussed above-fire, bomas, and altering tree cover-but only if the location, and ideally size and spacing, of these impacts varies in space and time. For example, as our research has illustrated, the increasing use of semi-permanent boma sites can be a cause of landscape degradation, whereas a more traditional shifting pattern of boma 
locations, durations, and spacing can minimize negative impacts on the land while increasing habitat heterogeneity and creating nutrient-rich hotspots that benefit both wildlife and livestock.

It is important to keep in mind that our results have emerged from a moderate to high productivity landscape where livestock (mostly cattle) are kept at moderate stocking rates. Our conclusions about the direct competitive and facilitative interactions between cattle and wild herbivores may take a different form in other contexts. For example, we would expect competition between cattle and wild herbivores to be more intense (and facilitation weaker) in a less productive system, or one with higher stocking densities. Competitive and facilitative dynamics may also take a different shape in systems where sheep, goats, camels, or other livestock species dominate. However, our findings on how bomas, changes in woody cover, and to some extent fire (depending on the productivity of the system and its resilience) can benefit wild herbivores would apply across a wide variety of landscapes and livestock systems.

From our interactions with pastoralists in Kenya and Ethiopia, it is clear that most are aware of the various positive and negative ways in which their activities can affect wildlife. However, few appear to be using these means to intentionally encourage wildlife, ecosystem health, or biodiversity. This is in part because the incentives to do so are absent or poorly developed, although this may be changing as outsiders are coming to value the services that rangelands can provide (see below). However, a more fundamental challenge for the future coexistence of wildlife and livestock is how to ensure moderate levels of grazing given a variety of constraints on livestock management. "Moderate grazing" typically means that $35-50 \%$ of the palatable forage is consumed before the area is allowed to recover (Holechek et al. 1999). In the past, smaller populations of mobile livestock ensured a more moderate grazing regime with adequate time for plants to recover. Today, pastoralists are more constrained in their movements and management options due to higher human and livestock populations and a variety of other factors beyond their control (e.g., land subdivision, colonial, and post-colonial land settlement schemes). These constraints will be coupled with continued increases in human population, improvements in veterinary practices, and growing expectations for large increases in the standard of living-posing a multitude of challenges for future livestock-wildlife coexistence. Even today, examples of pastoralists coexisting with wildlife (i.e., situations in which wildlife populations are not declining) are few and far between. Even the highly productive Mara/Serengeti and Ngorongoro ecosystems are experiencing large wildlife declines (Ogutu et al. 2011), probably because human and livestock densities are higher than they were historically. Wildlife increases in the Laikipia ecosystem are, at present, largely occurring on properties where livestock densities are more moderate (M. Kinnaird et al., unpublished data).

More optimistically, however, a number of initiatives and possible future scenarios give hope that pastoralists and wildlife can continue to co-exist in Africa as they have for centuries. Wildlife-based tourism enterprises (at present supported by external sources) on pastoralist-owned or -managed lands are operating with some success (both in terms of income generation and wildlife conservation) in various parts of East Africa, including Laikipia and the Maasai Mara. For example, in Laikipia and adjacent Samburu District, pastoralists on a number of group ranches have set aside conservation areas within their ranches. These areas are not grazed by domestic livestock year- 
round but rather are left for wildlife and as a reserve for livestock in the event of a drought. In the future, there may be formal markets for other types of ecosystem services-such as carbon sequestration or even provision of clean air and water-in pastoralist lands (World Initiative for Sustainable Pastoralism 2008).

Changing management systems and lifestyles may also portend new hope for wildlife and pastoralists to co-exist. Some previously mobile pastoralists who were encouraged to become sedentary and take ownership of small parcels of land by governments (Mwangi and Ostrom 2009) are now aggregating their holdings and returning to patterns of seasonal migration more similar to those of the past (Mwangi 2007). Particularly in arid and semi-arid ecosystems, pastoral mobility affords a more resilient and potentially more productive livestock system and is less likely to cause land degradation than a more sedentary, year-round grazing regime (Western et al. 2009a,b; Hesse and Cavanna 2010). In southern Kenya, wildlife populations fared far better where pastoral mobility was maintained compared to adjacent areas that were subdivided and settled (BurnSilver et al. 2008; Western et al. 2009a,b), and sedentarization had mixed effects on livestock production, being particularly detrimental on low-productivity sites (Boone et al. 2005; BurnSilver et al. 2008). Although the KLEE experiment was not designed to ask questions about livestock mobility, it does provide one example of wildlife coexisting with cattle in an area where cattle are grazed episodically rather than continuously. Mobility may also help to create or maintain greater landscape heterogeneity and reduce dry-season competition between wild herbivores and livestock. The possibility that traditional management practices such as seasonal migration and deliberate burns may in time be reinstated raises many possibilities for a sustainable relationship among people, livestock, and wildlife.

Additionally or alternatively, human populations in rural rangelands may decrease in years to come as people choose to move to urban centers (Young 2006) and a greater proportion of family income is generated from non-farm activities (Reid 2012). This may ease the livestock grazing pressure on the land, with benefits for wildlife. However, the demographic and economic shift away from pastoralism might not reduce overall livestock pressure on the land if, for example, urban residents (particularly the more well-to-do) continue to keep herds of livestock at their rural homes, as is the case in many parts of eastern and southern Africa. Conversely, supplemental income from wildlife may encourage greater tolerance for biodiversity and, along with more equitable sharing of benefits from livestock and greater empowerment of local communities in the national and international arena, could also help foster continued co-existence between wildlife and pastoralists (Reid 2012).

Yet another possibility is that the long-term ( $>50$ years) future of pastoralism in Africa will be so radically different from historical and contemporary pastoralism that many projections will be moot. For example, in Botswana and Kenya, rangeland landowners are increasingly absentee and hire third party pastoralists to manage their livestock-raising a whole new set of management issues. Nevertheless, livestock production in African's arid and semi-arid ecosystems-whatever form it takes-is likely to continue for the foreseeable future. Finding a path that reconciles this production with other societal values (biodiversity, ecosystem services) will remain an ongoing challenge. Current research is revealing that this challenge need not be insurmountable. 


\section{Competing interests}

The authors declare that they have no competing interests.

\section{Authors' contributions}

This review summarizes the work of multiple projects, with each section co-written by the people who conceived, designed, carried out, analyzed, and wrote up the original research. DK and TPY, wildlife section; FK andTPY, rodent section; WOO and TPY, cattle section; LMP and KEV, boma section; RLS, fire section; CR and MLW, tree density section. TPY wrote the first draft. CR did a major rewrite and handled all subsequent drafts. All the authors provided edits and read and approved the final manuscript.

\section{Acknowledgments}

We would like to thank Frederick Erii, John Lochikuya, Matthew Namoni, Jackson Ekadeli, and Patrick Etelej for their invaluable assistance in the field. We also thank Margaret Kinnaird, Michael Littlewood, and the Mpala Research Centre and its staff for their logistical support. The KLEE exclosure plots were built and maintained by grants from the James Smithson Fund of the Smithsonian Institution (to A.P. Smith), The National Geographic Society (4691-91), the African Elephant Program of the U.S. Fish and Wildlife Service (98210-0-G563) (to T.P. Young), and the National Science Foundation (LTREB BSR-97-07477, 03-16402, and 08-16453) (to T.P. Young, C. Riginos, K.E. Veblen, and K. Caylor). The boma, fire, and tree density research were also supported by the NSF LTREB grants, as well at NSF Graduate Research Fellowships (to R.L. Sensenig, K.E. Veblen, C. Riginos, L.M. Porensky, and M.L. Wilkerson) and NSF Doctoral Dissertation Improvement Grants (to R.L. Sensenig, C. Riginos, and L.M. Porensky). Rodent research was funded by NSF (CAREER) and the National Geographic Society (to F. Keesing). We also thank Cary Farley and two anonymous reviewers for their helpful comments on the manuscript.

\section{Author details}

${ }^{1}$ Department of Zoology and Physiology, University of Wyoming, Laramie, WY 82071, USA. ${ }^{2}$ Mpala Research Centre, P. O. Box 555, Nanyuki, Kenya. ${ }^{3}$ Department of Plant Sciences, University of California, Davis, CA 95616, USA. ${ }^{4}$ Wildland Resources Department, 5230 Old Main Hill, Utah State University, Logan, UT 84322, USA. ${ }^{5}$ Department of Biology, Goshen College, Goshen, IN 46526, USA. ${ }^{6}$ Department of Biological Sciences, University of Nairobi, Nairobi, Kenya. ${ }^{7}$ Department of Biology, Bard College, Annandale-on-Hudson, NY 12504, USA.

Received: 7 November 2011 Accepted: 27 January 2012

Published: 28 September 2012

\section{References}

Archer S (2010) Rangeland conservation and shrub encroachment: new perspectives on an old problem. In: du Toit J Kock R, Deutsch J (eds) Wild rangelands: Conserving wildlife while maintaining livestock in semi-arid ecosystems. Wiley-Blackwell, Oxford, UK, pp 53-97

Atickem A, Williams S, Bekele A, Thirgood S (2010) Livestock predation in the Bale Mountains, Ethiopia. African Journal of Ecology 48:1076-1082

Augustine DJ, Young TP, Veblen KE, Riginos C, Goheen JR (2011) Pathways for positive cattle-wildlife interactions in semi-arid rangelands. Smithsonian Contributions to Zoology 632:55-71

Augustine DJ (2003) Long-term, livestock-mediated redistribution of nitrogen and phosphorus in an East African savanna. Journal of Applied Ecology 40:137-149

Augustine DJ (2004) Influence of cattle management on habitat selection by impala on central Kenyan rangeland. Journal of Wildlife Management 68:916-923

Blackmore AC, Mentis MT, Scholes RJ (1990) The origin and extent of nutrient-enriched patches within a nutrient-poor savanna in South Africa. Journal of Biogeography 17:463-470

Boone RB, BurnSilver SB, Thornton PK, Worden JS, Galvin KA (2005) Quantifying declines in livestock due to land subdivision. Rangeland Ecology and Management 58:523-532

Boutton TW, Tieszen LL, Imbamba SK (1988) Seasonal changes in the nutrient content of East African grassland vegetation. African Journal of Ecology 26:103-115

Boyd C, Blench R, Bourn D, Drake L, Stevenson P (1999) Reconciling interests among wildlife and people in eastern Africa: A sustainable livelihoods approach, vol 45, Natural Resource Perspectives. ODI, London

Bradbury JW, Vehrencamp SL, Clifton KE, Clifton LM (1996) The relationship between bite rate and local forage abundance in wild Thomson's gazelles. Ecology 77:2237-2255

BurnSilver SB, Worden J, Boone RB (2008) Processes of fragmentation in the Amboseli ecosystem, southern Kajiado District, Kenya. In: Galvin KA, Reid RS, Behnke RH, Hobbs NT (eds) Fragmentation in semi-arid and arid landscapes: Consequences for human and natural systems. Springer, Berlin, pp 225-253

Dunham KM, Robertson EF, Swanepoel CM (2003) Population decline of tsessebe antelope (Damaliscus lunatus /unatus) on a mixed cattle and wildlife ranch in Zimbabwe. Biological Conservation 113:111-124

Duncan P, Foose TJ, Gordon I, Gakahu CG, Lloyd M (1990) Comparative nutrient extraction from forages by grazing bovids and equids: A test of the nutritional model of equid/bovid competition and coexistence. Oecologia 84:411-418

du Toit J, Kock J, Deutsch J (eds) (2010) Wild rangelands: Conserving wildlife while maintaining livestock in semi-arid ecosystems. Wiley-Blackwell, Oxford, UK

Ensminger J, Rutten A (1991) The political-economy of changing property-rights—dismantling a pastoral commons. American Ethnologist 18:683-699

Estes RD, Atwood JL, Estes AB (2006) Downward trends in Ngorongoro Crater ungulate populations 1986-2005: Conservation concerns and the need for ecological research. Biological Conservation 131:106-120

Fratkin EM, Roth EA, Nathan MA (1999) When nomads settle: The effects of commoditization, nutritional change, and formal education on Ariaal and Rendille pastoralists. Current Anthropology 40:729-735 
Georgiadis NJ, Olwero JGN, Ojwang G, Romanach SS (2007) Savanna herbivore dynamics in a livestock-dominated landscape: I. Dependence on land use rainfall density and time. Biological Conservation 137:461-472

Georgiadis NJ (2011) Introduction: Conserving wildlife in Kenya's Ewaso landscape. Smithsonian Contributions to Zoology 632:1-10

Gichohi HW (1992) The effects of fire and grazing on grasslands of Nairobi National Park. University of Nairobi, MSc Dissertation

Gillson L (2004) Testing non-equilibrium theories in savannas: 1400 years of vegetation change in Tsavo National Park, Kenya. Ecological Complexity 1:281-298

Goheen JR, Palmer TM, Keesing F, Riginos C, Young TP (2010) Large herbivores facilitate savanna tree establishment via diverse and indirect pathways. Journal of Animal Ecology 79:372-382

Gregory NC, Sensenig RL (2010) Effects of controlled fire and livestock grazing on bird communities in East African savannas. Conservation Biology 24:1606-1616

Grootenhuis JG (ed) (1999) 25 Years of wildlife disease research in Kenya, Nairobi. Kenya Agricultural Research Institute, Nairobi, Kenya

Gwynne MD, Bell RHV (1968) Selection of vegetation components by grazing ungulates in the Serengeti National Park. Nature 220:390-393

Hazell PBR, Hess U (2010) Drought insurance for agricultural development and food security in dryland areas. Food Security 2:395-405

Heady HF (1960) Range management in East Africa. Kenya Department of Agriculture. Government Printer, Nairobi, Kenya

Herlocker DJ (1996) Rangeland degradation in arid and semi-arid Africa. In: McClanahan TR, Young TP (eds) East African ecosystems and their conservation. Oxford University Press, New York, pp 266-267

Hesse C, Cavanna S (2010) Modern and mobile: The future of livestock production in Africa's drylands. International Institute for Environment and Development and SOS Sahel, UK

Holechek JL, Gomez H, Molinar F, Galt D (1999) Grazing studies: What we've learned. Rangelands 21:12-16

Homewood KM, Rodgers WA (1984) Pastoralism and conservation. Human Ecology 12:431-441

Keesing FL (1998) Impacts of ungulates on the demography and diversity of small mammals in central Kenya. Oecologia 116:381-389

Keesing F (2000) Cryptic consumers and the ecology of an African savanna. Bioscience 50:205-216

Kinyamario Jl, Macharia JNM (1992) Above-ground standing crop, protein content and dry matter digestibility of a tropical grassland range in the Nairobi National Park, Kenya. African Journal of Ecology 30:33-41

Kock R, Kock M, Cleaveland S, Thomson G (2010) Health and disease in wild rangelands. In: du Toit J, Kock R, Deutsch J (eds) Wild rangelands: Conserving wildlife while maintaining livestock in semi-arid ecosystems. Wiley-Blackwell, Oxford, UK, pp 98-128

Lamprey R, Reid RS (2004) Expansion of human settlement in Kenya's Maasai Mara: What future for pastoralism and wildlife? Journal of Biogeography 31:997-1032

Maclean JE, Goheen JR, Palmer TM, Young TP (2011) Small mammals limit tree population growth in an African savanna. Ecology 92:1626-1636

Moleele NM, Perkins JS (1998) Encroaching woody plants species and boreholes: Is cattle density the main driving factor in the Olifants Drift communal grazing lands, south-eastern Botswana. Journal of Arid Environments 40:245-253

Moleele NM, Ringrose S, Matheson W, Vanderpost C (2002) More woody plants? The status of bush encroachment in Botswana's grazing areas. Journal of Environmental Management 64:3-11

Muchiru AN, Western D, Reid RS (2009) The impact of abandoned pastoral settlements on plant and nutrient succession in an African savanna ecosystem. Journal of Arid Environments 73:322-331

Muchiru AN, Western DJ, Reid RS (2008) The role of abandoned pastoral settlements in the dynamics of African large herbivore communities. Journal of Arid Environments 72:940-952

Mwangi E (2007) Subdividing the commons: Distributional conflict in the transition from collective to individual property rights in Kenya's Maasailand. World Development 35:815-834

Mwangi E, Ostrom E (2009) Top-down solutions: looking up from East Africa's rangelands. Environment 51:34-44

Odadi WO, Young TP, Okeyo-Owuor JB (2007) The effects of wild herbivores on cattle diet in Laikipia rangeland, Kenya. Rangeland Ecology and Management 60:179-185

Odadi WO, Young TP, Okeyo-Owuor JB (2009) Behavioural responses of cattle to shared foraging with wild herbivores in an East African rangeland. Applied Animal Behavior Science 116:120-125

Odadi WO, Abdulrazak AS, Karachi MM, Young TP (2011) African wild ungulates compete with or facilitate cattle depending on season. Science 333:1755-1757

Okello BD, Young TP, Riginos C, Kelly D, O'Connor T (2008) Short-term survival and long-term mortality of Acacia drepanolobium after a controlled burn in Laikipia, Kenya. African Journal of Ecology 46:395-401

Ogada D, Gadd ME, Ostfeld RS, Young TP, Keesing F (2008) Impacts of large herbivores on bird diversity and abundance in an African savanna. Oecologia 156:387-397

Ogutu JO, Piepho H-P, Dublin HT, Bhola N, Reid RS (2009) Dynamics of Mara-Serengeti ungulates in relation to land use changes. Journal of Zoology 278:1-14

Ogutu JO, Piepho H-P, Reid RS, Rainy ME, Kruska RL, Worden JS, Nyabenge M, Hobbs NT (2010) Large herbivore responses to water and settlements in savannas. Ecological Monographs 80:241-266

Ogutu JO, Owen-Smith N, Piepho H-P, Said MY (2011) Continuing wildlife population declines and range contraction in the Mara region of Kenya during 1977-2009. Journal of Zoology 284:99-109

Osofsky SA, Cleaveland S, Karesh WB, Kock MD, Nyhus PJ, Starr L, Yang A (eds) (2005) Conservation and development interventions at the wildlife/livestock interface: Implications for wildlife, livestock and human health. IUCN, Gland, Switzerland and Cambridge, UK

Ottichilo WK, De Leeuw J, Skidmore AK, Prins HHT, Said MY (2000) Population trends of large non-migratory wild herbivores and livestock in the Masai Mara ecosystem Kenya between 1977 and 1997. African Journal of Ecology 38:202-216 
Porensky LM (2011) When edges meet: interacting edge effects in an African savanna. Journal of Ecology 99:923-934 Porensky LM, Bucher SF, Veblen KE, Treydte AC, Young TP (in review) Large herbivores alter edge effects around ecosystem hotspots in an African savanna

Porensky LM, Veblen KE (2012) Grasses and large herbivores reinforce landscape heterogeneity by excluding trees from ecosystem hotspots. Oecologia 168:749-759

Pringle RM, Young TP, Rubenstein DI (2007) Primary productivity and the strength of herbivore-initiated interaction cascades. PNAS 104:193-197

Prins HHT (1992) The pastoral road to extinction — competition between wildlife and traditional pastoralism in East Africa. Environmental Conservation 19:117-123

Prins HHT (2000) Competition between wildlife and livestock in Africa. In: Prins HHT, Grootenhuis JG, Dolan TT (eds) Wildlife conservation by sustainable use. Kluwer Academic Publishers, Boston, pp 51-80

Reid RS (2012) Savannas of our birth. University of California Press, Berkeley, CA, in press

Reid RS, Ellis JE (1995) Impacts of pastoralists on woodlands in South Turkana, Kenya: Livestock-mediated tree recruitment. Ecological Applications 5:978-992

Riginos C (2009) Grass competition suppresses savanna tree growth across multiple demographic stages. Ecology 90:335-340

Riginos C, Grace JB (2008) Savanna tree density, herbivores, and the herbaceous community: Bottom-up versus topdown effects. Ecology 89:2228-2238

Riginos C, Grace JB, Augustine DJ, Young TP (2009) Local versus landscape-scale effects of savanna trees on grasses. Journal of Ecology 97:1337-1345

Riginos C, Young TP (2007) Positive and negative effects of grasses and wild and domestic herbivores on Acacia saplings in an East African savanna. Oecologia 153:985-995

Ringrose S, Vanderpost C, Matheson W (1996) The use of integrated remotely sensed and GIS data to determine causes of vegetation cover change in southern Botswana. Applied Geography 16:225-242

Sensenig RL, Demment M, Laca EA (2010) Allometric scaling predicts preferences for burned patches in a guild of East African grazers. Ecology 91:2898-2907

Sitters J, Heitkonig IMA, Holmgren M, Ojwang GSO (2009) Herded cattle and wild grazers partition water but share forage resources during dry years in East African savannas. Biological Conservation 142:738-750

Spalinger DE, Hobbs NT (1992) Mechanisms of foraging in mammalian herbivores-new models of functionalresponse. American Naturalist 140:325-348

Soderstrom B, Reid RS (2010) Abandoned pastoral settlements provide concentrations of resources for savanna birds. Acta Oecologica International Journal of Ecology 36:184-190

Sundaresan SR, Fischhoff IR, Hartung HM, Akilong P, Rubenstein DI (2007) Habitat choice of Grevy's zebras (Equus grevyi) in Laikipia, Kenya. African Journal of Ecology 46:359-364

Sundaresan SR, Riginos C (2010) Lessons learned from biodiversity conservation in the private lands of Laikipia, Kenya. Great Plains Research 20:17-27

Treydte AC, Riginos C, Jeltsch F (2010) Enhanced use of beneath-canopy vegetation by grazing ungulates in African savannahs. Journal of Arid Environments 74:1597-1603

Ungar ED, Noy-Meir I (1988) Herbage intake in relation to availability and sward structure: Grazing processes and optimal foraging. Journal of Applied Ecology 25:1045-1082

Veblen KE (2008a) Livestock and wildlife effects on the successional development of a savanna landscape mosaic in East Africa. University of California, Davis. PhD Dissertation

Veblen KE (2008b) Season- and herbivore-dependent competition and facilitation in a semiarid savanna. Ecology 89:1532-1540

Veblen KE (2012) Savanna glade hotspots: plant community development and synergy with large herbivores. Journal of Arid Environments 78:119-127

Veblen KE, Young TP (2010) Contrasting effects of cattle and wildlife on the vegetation development of a savanna landscape mosaic. Journal of Ecology 98:993-1001

Western D, Dunne T (1979) Environmental aspects of settlement site decisions among pastoral Maasai. Human Ecology 7:75-98

Western D, Groom R, Worden J (2009a) The impact of subdivision and sedentarization of pastoral lands on wildlife in an African savanna ecosystem. Biological Conservation 142:2538-2546

Western D, Russell S, Cuthill I (2009b) The status of wildlife in protected areas compared to non-protected areas of Kenya. PLOS ONE 4:e6140

Wigley BJ, Bond WJ, Hoffman MT (2010) Thicket expansion in a South African savanna under divergent land use: Local vs. global drivers? Global Change Biology 16:964-976

Witt ABR, Nongogo AX (2011) The impact of fire, and its potential role in limiting the distribution of Bryophyllum delagoense (Crassulaceae) in southern Africa. Biological Invasions 13:125-133

Woodroffe R (2011) Demography of a recovering African wild dog (Lycaon pictus) population. Journal of Mammalogy 92:305-315

World Initiative for Sustainable Pastoralism (2008) Forgotten services, diminished goods: Understanding the agroecosystem of pastoralism., WISP Policy Note No. 8

Young TP (2006) Declining rural populations and the future of biodiversity: Missing the forest for the trees? Journal of International Wildlife Law \& Policy 9:319-334

Young TP, Okello B, Kinyua D, Palmer TM (1998) KLEE: the Kenya long-term exclosure experiment. African Journal of Range and Forage Science 14:94-102

Young TP, Palmer TM, Gadd ME (2005) Competition and compensation among cattle, zebras, and elephants in a semiarid savanna in Laikipia, Kenya. Biological Conservation 122:351-359

Young TP, Patridge N, Macrae A (1995) Long-term glades in acacia bushland and their edge effects in Laikipia, Kenya. Ecological Applications 5:97-108 
Zimmerman A, Baker N, Inskip C, Linnel JDC, Marchini S, Odden J, Rasmussen G, Treves A (2010) Contemporary views of human-carnivore conflicts on wild ragnelands. In: du Toit JT, Kock R, Deutsch JC (eds) Wild Rangelands: Conserving wildlife while maintaining livestock in semi-arid ecosystems. Wiley-Blackwell, Oxford, UK, pp 129-151

Zwaagstra L, Sharif Z, Wambile A, de Leeuw J, Said MY, Johnson N, Njuki J, Ericksen P, Herrero M (2010) An assessment of the response to the 20082009 drought in Kenya. In: A report to the European Union Delegation to the Republic of Kenya. International Livestock Research Institute (ILRI), Nairobi, Kenya

doi:10.1186/2041-7136-2-10

Cite this article as: Riginos et al: Lessons on the relationship between livestock husbandry and biodiversity from the Kenya Long-term Exclosure Experiment (KLEE). Pastoralism: Research, Policy and Practice 2012 2:10.

Submit your manuscript to a SpringerOpen ${ }^{\circ}$ journal and benefit from:

- Convenient online submission

- Rigorous peer review

- Immediate publication on acceptance

- Open access: articles freely available online

- High visibility within the field

- Retaining the copyright to your article 